\title{
Primary anorectal malignant melanomas: retrospective analysis of 11 cases in a single center
}

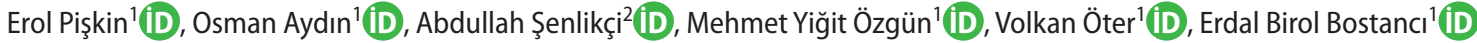 \\ ${ }^{1}$ Clinic of Surgical Gastroenterology, Ankara City Hospital, Ankara, Turkey \\ ${ }^{2}$ Clinic of Surgical Gastroenterology, Ankara Training and Research Hospital, Ankara, Turkey
}

\section{ABSTRACT}

Objective: Anorectal malignant melanoma is a rare tumor with poor prognosis. In this study, it was aimed to present our surgical results by reviewing the literature retrospectively in 11 patients who underwent surgery for ARMM in our clinic.

Material and Methods: The patients who underwent surgery for anorectal malignant melanoma in Yuksek Ihtisas Training and Research Hospital between 2007-2018 were included in the study.

Results: Four patients were males and seven were females. Mean age was 54.18. The tumor was in the rectum in 4 cases, in the anorectal region in 3 cases and in the anal canal in 4 cases. Wide local excision was performed in 3 cases and APR was performed in 8 cases. Four of the cases were stage l, 6 were stage II and 1 was stage III. Mean tumor size was $4.73 \mathrm{~cm}$, and mean tumor depth was $13.6 \mathrm{~mm}$. Mean number of metastatic lymph nodes was 10.37 . Median survival was 12 months.

Conclusion: Anorectal malignant melanoma is a type of tumor diagnosed in late and advanced stages due to lack of specific findings. Although ARMM is rare, when rectal bleeding, pain, hemorrhoids and changes in bowel habits are observed, ARMM should be kept in mind.

Keywords: Anorectal malignant melanoma, abdominoperineal resection, wide local excision, prognosis

Cite this article as: Pişkin E, Aydın O, Şenlikçi A, Özgün MY, ÖterV, Bostancı EB. Primaryanorectal malignant melanomas: retrospective analysis of 11 cases in a single center. Turk J Surg 2021; 37 (1):63-67.

\section{Corresponding Author}

Erol Pişkin

E-mail: erol90279@gmail.com

Received: 20.04 .2020

Accepted: 12.08 .2020

Available Online Date: 22.03 .2021

OCopyright 2021 by Turkish Surgical Society Available online at www.turkjsurg.com

DOI: $10.47717 /$ turkjsurg.2021.4810

\section{INTRODUCTION}

Anorectal malignant melanoma (ARMM) accounts for less than $1 \%$ of all colorectal malignancies and $1-2 \%$ of all melanomas (1). Its prognosis is very poor. Median survival is 24 months and 5-year survival is 10\% (2). The first case presentation of ARMM was made by Moore in 1857 (3). Patients usually die after metastatic disease. Wide local excision (WLE) or abdominoperineal resection (APR) are the methods of surgical treatment. In a meta-analysis, it has been shown that APR had no superiority to WLE on mean survival, but local recurrence was observed less in APR. Due to the fact that there is no difference in survival in localized disease without lymph node metastasis, WLE provides better life comfort and less morbidity (4).

In this study, it was aimed to present our surgical results by reviewing the literature retrospectively in 11 patients who underwent surgery for ARMM in our clinic.

\section{MATERIAL and METHODS}

The patients who underwent surgery for anorectal malignant melanoma in Yuksek intisas Training and Research Hospital between 2007-2018 were included in the study. Patients with distant metastasis at the time of diagnosis and who did not accept surgery were excluded from the study. Data were obtained retrospectively from patient files. Patients were evaluated in terms of age, sex, tumor localization, stage, surgery, preoperative investigations, symptoms, tumor size, tumor depth, RO resection, lymph node metastasis and survival. Surgical approach was preferred according to whether the patient would allow permanent colostomy or not. APR was recommended firstly to all of the patients included in the study. WLE was applied to patients who did not accept APR. Tumor stage (TNM stage) was defined according to the American Joint Committee on Cancer classification (AJCC, $7^{\text {th }}$ edition). 
SPSS software version 17 (SPSS Inc., Chicago, IL, USA) was used in this study for statistical analysis. Descriptive data were expressed as mean or median (range). Categorical variables were described using frequency distributions. Survival was calculated using the Kaplan-Meier method. Length of survival was calculated as the period from the date of initial operation to the date of death or last follow-up.

\section{RESULTS}

Eleven patients who were operated on for anorectal malignant melanoma were included in the study. Four (36.36\%) of the cases were males and 7 (63.63\%) were females. Mean age was 54.18 (38-67). Rectal pain was present in 3 (27.27\%) patients and rectal bleeding was present in $8(72.72 \%)$ patients. Hemorrhoidectomy was performed in 2 of the cases due to rectal bleeding and pathology was reported as malignant melanoma. All patients underwent colonoscopy and abdominal tomography for preoperative evaluation. Four cases underwent PET/CT, 1 case MRI and 2 cases EUS for staging. When evaluated for the location of the tumor, the tumor was in the rectum in 4 (36.36\%) cases, in the anorectal region in $3(27.27 \%)$ cases and in the anal canal in 4 $(36.36 \%)$ cases. Local excision was performed in $3(27.27 \%)$ of the cases, and APR was performed in 8 (72.72\%) of the cases. Postop- erative complication was observed in only one patient. Ostomy separation was observed, and ostomy revision was performed. Recurrence or metastasis was observed in 4 patients postoperatively. Two of them had recurrence at the local excision site, and the other two patients had multiple liver metastasis. Ten (90.90\%) cases died during postoperative follow-up. Median survival was 12 (1-53) months (Table 1). 5-year survival was 9.09\%. Four (36.36\%) of the cases were stage I, 6 (54.54\%) were stage II and 1 (9.09\%) were stage III. Mean tumor size was 4.73 (1.5-12) $\mathrm{cm}$. Mean tumor depth was 13.6 (1.3-25) mm.

R0 resection could not be performed in only 1 of the 11 patients included in the study. Wide local excision was performed in 3 cases so lymph node dissection could not be performed (Figure $1,2)$. Lymph node metastasis was observed in only the remaining 6 of 8 cases. Mean number of metastatic lymph nodes was 10.37 (0-25) (Table 2).

\section{DISCUSSION}

ARMMs are rare aggressive tumors that constitute $0.05 \%$ of all colorectal tumors (5). They are observed more frequently in the 6 th decade and more in females than males (6). Similar results were observed in our study with the literature. In one study, ARMM has been observed in $65 \%$ of the anal canal and anoractal

Table 1. Demographic characteristics of the cases

\begin{tabular}{|c|c|c|c|c|c|c|c|c|c|}
\hline No. & Age & Sex & Symptom & Preop examination & Site & Surgery & $\begin{array}{l}\text { Complica- } \\
\text { tion }\end{array}$ & $\begin{array}{c}\text { Recurrence or } \\
\text { Metastasis }\end{array}$ & $\begin{array}{l}\text { Survival } \\
\text { (Month) }\end{array}$ \\
\hline 1 & 42 & Male & $\begin{array}{c}\text { Rectal } \\
\text { bleeding }\end{array}$ & Colonoscopy, CT & $\begin{array}{l}\text { Anorectal } \\
\text { region }\end{array}$ & APR (2007) & - & - & 7 \\
\hline 2 & 56 & Female & $\begin{array}{c}\text { Rectal } \\
\text { bleeding }\end{array}$ & Colonoscopy, CT & Anal canal & APR (2008) & - & - & 12 \\
\hline 3 & 67 & Female & Rectal pain & Colonoscopy, CT & $\begin{array}{l}\text { Anorectal } \\
\text { region }\end{array}$ & WLE (2009) & - & + & 6 \\
\hline 4 & 43 & Male & $\begin{array}{c}\text { Rectal } \\
\text { bleeding }\end{array}$ & $\begin{array}{c}\text { Colonoscopy, CT, } \\
\text { PET/CT }\end{array}$ & $\begin{array}{l}\text { Anorectal } \\
\text { region }\end{array}$ & APR (2009) & - & + & 12 \\
\hline 5 & 65 & Female & $\begin{array}{c}\text { Rectal } \\
\text { bleeding }\end{array}$ & $\begin{array}{c}\text { Colonoscopy, CT, } \\
\text { MRI }\end{array}$ & Rectum & APR (2009) & $\begin{array}{l}\text { Ostomy } \\
\text { seperation }\end{array}$ & + & 17 \\
\hline 6 & 67 & Male & $\begin{array}{c}\text { Rectal } \\
\text { bleeding }\end{array}$ & Colonoscopy, CT & Rectum & APR (2011) & - & - & 1 \\
\hline 7 & 56 & Female & $\begin{array}{c}\text { Rectal } \\
\text { bleeding }\end{array}$ & $\begin{array}{c}\text { Colonoscopy, EUS, } \\
\text { CT }\end{array}$ & Anal canal & APR (2012) & - & + & $\begin{array}{l}21 \text { (lost in } \\
\text { follow-up) }\end{array}$ \\
\hline 8 & 38 & Female & $\begin{array}{c}\text { Rectal } \\
\text { bleeding }\end{array}$ & $\begin{array}{c}\text { Colonoscopy, CT, } \\
\text { PET/CT }\end{array}$ & Rectum & APR (2014) & - & - & 53 \\
\hline 9 & 61 & Male & $\begin{array}{c}\text { Rectal } \\
\text { bleeding }\end{array}$ & $\begin{array}{c}\text { Colonoscopy, } C T \text {, } \\
\text { PET/CT }\end{array}$ & Anal canal & WLE (2017) & - & - & 17 \\
\hline 10 & 46 & Female & Rectal pain & $\begin{array}{c}\text { Colonoscopy, CT, } \\
\text { PET/CT }\end{array}$ & Anal canal & WLE (2017) & - & - & 16 \\
\hline 11 & 55 & Female & Rectal pain & $\begin{array}{c}\text { Colonoscopy, EUS, } \\
\text { CT }\end{array}$ & Rectum & APR (2013) & - & - & 9 \\
\hline
\end{tabular}




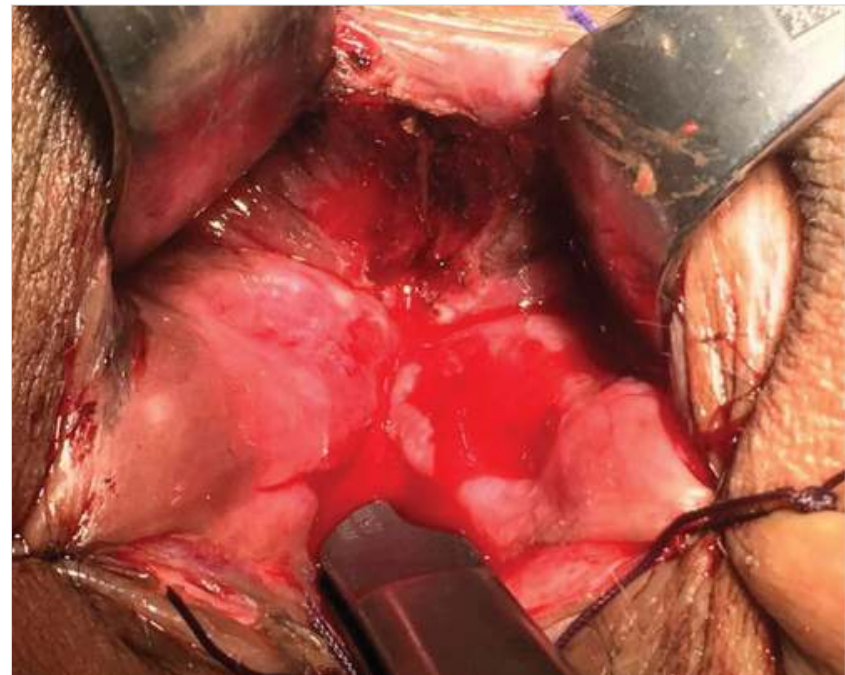

Figure 1. Excision area after wide local excision.
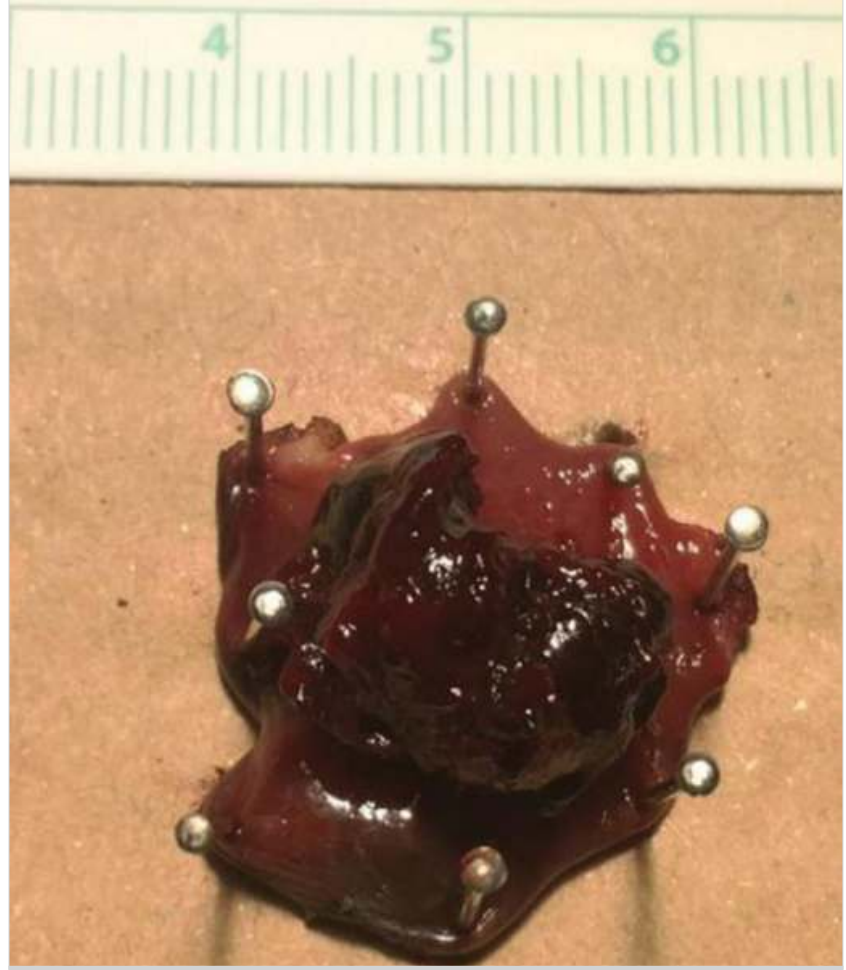

Figure 2. WLE specimen excised in the anal canal.

region, in 35\% of the distal rectum, and in our study, the tumor was observed in 36\% of the distal rectum (7). Male sex, perineural invasion, depth of invasion, lymph node metastasis and distant metastasis are poor prognostic factors and indicates that the patient's survival will be short.

More than $40 \%$ of the patients with submucosal infiltration in ARMM have lymph node metastasis. 5-year survival in patients with lymph node metastasis is close to $0 \%$. Lymphatic spread is to inguinal and/or iliac lymph nodes and perirectal lymph nodes (5). Negative surgical margins in primary mucosal malignant melanoma increase mean survival (6).

Abdominal ultrasonography, endorectal ultrasonography (EUS), computed tomography (CT), magnetic resonance (MRI) and PET/CT are used for staging in ARMM. EUS is used to determine the depth of invasion, abdominal CT is used to detect liver and lung metastasis and MRI is used to determine liver metastasis and depth of invasion (8). PET-CT is recommended for staging in the studies. Due to high metabolic rate of tumor cells and high FDG uptake in malignant melanoma patients, it is an effective method for staging and is superior to other imaging methods (5).

Traditionally, APR is the best treatment option because it provides more local control in ARMM. However, there are retrospective studies showing that mean survival in patients undergoing wide local excision is similar to APR (7). Patients undergoing WLE have more local recurrence, but in the absence of distant metastases, local recurrence can be eliminated by re-excision. In addition, when WLE is performed, a better quality of life is achieved, fewer complications are observed and colostomy does not cause difficulties in life compared to APR patients (4).

When there is mesorectal and mesenteric lymph node metastasis, $\mathrm{R} 0$ resection cannot be performed with WLE. Therefore, staging is important before selecting the surgical method. Although MRI and endorectal ultrasonography are effective in evaluating mesenteric lymph node metastasis in rectal tumor, it is not sufficient to evaluate lymph node metastasis in anorectal malignant melanoma. In the study of Wang et al., when tumor size is over 3 $\mathrm{cm}$, WLE should not be performed because of the possibility of lymph node metastasis (9).

Rectal hemorrhage is the most common symptom in ARMM and occurs in 53\% - 89\% of the cases. Other symptoms are suspected hemorrhoids, pain, anal mass, changes in bowel habits, and itching. High LDH and YKL-40 levels also increase the suspicion of anorectal malignant melanoma. A very small number of patients are examined with mass in the inguinal region (10). In our study, $72.72 \%$ of the patients presented with rectal bleeding complaints. Due to the rarity of ARMM and non-specific clinical findings, misdiagnosis is very common. Early symptoms of ARMM may be misdiagnosed with benign lesions such as thrombosed hemorrhoids, hemorrhoids and rectal adenomas. The reasons for misdiagnosis are that clinicians do not have sufficient knowledge, lack of specific clinical findings and difficult pathological diagnosis (11).

Patients present at advanced stages due to nonspecific clinical findings in ARMM. In the study of Hicks et al., half of the cases have been diagnosed in stage II and stage III. In the same study, median tumor thickness was $5.5 \mathrm{~mm}$, and in more than half of 
Table 2. Histopathological features of the cases

\begin{tabular}{|c|c|c|c|c|c|}
\hline Patient No. & Stage & Tumor Size $(\mathrm{cm})$ & Tumor Depth (mm) & Ro Resection & Lymph Node Metastasis \\
\hline 1 & $\|$ & 3.5 & 15 & + & 6 \\
\hline 2 & $\|$ & 3.3 & 18 & + & 16 \\
\hline 3 & 1 & 2.5 & 12 & - & - \\
\hline 4 & $\|$ & 4 & 25 & + & 9 \\
\hline 5 & $\|$ & 6 & 9 & + & 3 \\
\hline 6 & III & 12 & 20 & + & 24 \\
\hline 7 & । & 1.5 & 8 & + & 0 \\
\hline 8 & $\|$ & 6 & 21 & + & 0 \\
\hline 9 & 1 & 2 & 1.3 & + & - \\
\hline 10 & I & 1.8 & 1.3 & + & - \\
\hline 11 & $\|$ & 9.5 & 19 & + & 25 \\
\hline
\end{tabular}

the patients, tumor depth was deeper than $4.0 \mathrm{~mm}$ (12). In our study, the rate of stage I patients was found to be $36.36 \%$. Mean tumor depth was $13.6 \mathrm{~mm}$. We believe that mean survival time is lower than the literature due to the higher stage of the patients and more tumor depth in our study.

To conclude, ARMM is a rare and rapidly progressing disease with poor prognosis. ARMM is diagnosed at advanced stages due to lack of specific symptoms and has a low survival rate. Radical surgery provides longer survival advantage in early-stage tumors. ARMM should be kept in mind in patients with rectal bleeding, rectal pain and palpable mass or hemorrhoids since the most important factor in survival is the early diagnosis of the disease.

Ethics Committee Approval: The approval for this study was obtained from Ministry of Health Ankara City Hospital Clinical Research Ethics Committee (Decision no: E.Kurul-E1-20-1399 Date: 23.12.2020).

Peer-review: Externally peer-reviewed.

Author Contributions: Concept - E.P., V.Ö.; Design - E.P., V.Ö.; Supervision E.B.B.; Materials - O.A., M.Y.Ö.; Data Collection and/or Processing - O.A.; A.Ş.; Literature Review - O.A., M.Y.Ö.; Writing Manuscript - E.P., A.Ş.; Critical Reviews - E.B.B.

Conflict of Interest: The authors declare that they have no conflict of interest.

Financial Disclosure: The authors declared that this study has received no financial support.

\section{REFERENCES}

1. Pack GT, Oropeza R. A comparative study of melanoma and epidermoid carcinoma of the anal canal: A review of 20 melanomas and 29 epidermoid carcinomas (1930 to 1965). Dis Colon Rectum 1967; 10: 161-176. [CrossRef]

2. Keskin S, Tas F, Karabulut S, Yildiz I, Kiliç L, Ciftci R, et al. The role of surgical methods in the treatment of anorectal malignant melanoma (AMM). Acta Chir Belg 2013; 113: 429-33. [CrossRef]
3. Moore WD. Recurrent melanosis of the rectum after previous removal from the verge of the anus in a man aged sixty-five. Lancet 1857;1:290-4. [CrossRef]

4. Matsuda A, Miyashita M, Matsumoto S, Takahashi G, Matsutani T, Yamada $T$, et al. Abdominoperineal resection provides better local control but equivalent overall survival to local excision of anorectal malignant melanoma. Ann Surg 2015; 261 (4): 670-7. [CrossRef]

5. Falch C, Mueller S, Kirschniak A, Braun M, Koenigsrainer A, Klumpp B. Anorectal malignant melanoma: curative abdominoperineal resection: patient selection with 18F-FDG-PET/CT. W J Surg Oncol 2016; 14: 185-93. [CrossRef]

6. Tse JY, Chan MP, Zukerberg LR, Nazarian RM. Assessment of melanocyte density in anorectal mucosa for the evaluation of surgical margins in primary anorectal melanoma. Am J Clin Pathol 2016; 145: 626-34. [CrossRef]

7. Miguel I, Freire J, Passos MJ, Moreira A. Anorectal malignant melanoma: retrospective analysis of management and outcome in a single Portuguese Institution. Med Oncol 2015; 32: 443-5. [CrossRef]

8. Malaguarnera G, Madeddu R, Catania VE, Bertino G, Morelli L, Perrota $R E$, et al. Anorectal mucosal melanoma. Oncotarget 2018; 9(9): 8785800. [CrossRef]

9. Wang M, Zhang Z, Zhu J, Sheng W, Lian P, Liu F, et al. Tumour diameter is a predictor of mesorectal and mesenteric lymph node metastases in anorectal melanoma. Colorectal Disease 2013; 15: 1086-92. [CrossRef]

10. Latteri S, Teodoro M, Malaguarnera M, Mannino M, Curro G, La Greca G. Abdominal perineal resection or wilde local excision in primary anorectal malignant melanoma. Case report and review. Ann Med Surg 2017; 19: 74-7. [CrossRef]

11. Che X, Zhao DB, Wu YK, Wang CF, Cai JQ, Shao YF, et al. Anorectal malignant melanomas: Retrospective experience with surgical management. World J Gastroenterol 2011; 17(4): 534-9. [CrossRef]

12. Hicks CW, Pappou EP, Magruder JT, Gazer B, Fang S, Wick EC, et al. Clinicopathologic presentation and natural history of anorectal melanoma A case series of 18 patients. JAMA Surgery 2014; 149(6): 608-11. [CrossRef] 


\section{ORIJINAL ÇALIŞMA/OLGU SERISi-ÖZET}

\section{Primer anorektal malign melanomları: tek bir merkezde 11 olgunun retrospektif analizi}

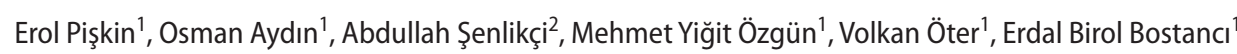

1 Ankara Şehir Hastanesi, Cerrahi Gastroenteroloji Kliniği, Ankara, Türkiye

${ }^{2}$ Ankara Eğitim ve Araştırma Hastanesi, Cerrahi Gastroenteroloji Kliniği, Ankara, Türkiye

\section{ÖZET}

Giriş ve Amaç: Anorektal malign melanom kötü prognozu olan nadir bir tümördür. Bu çalışmada, kliniğimizde ARMM ameliyatı geçiren 11 hastada literatürü retrospektif olarak inceleyerek cerrahi sonuçlarımızı sunmayı amaçladık.

Gereç ve Yöntem: 2007-2018 yılları arasında Yüksek Ihtisas Eğitim ve Araştırma Hastanesinde anorektal malign melanom nedeniyle ameliyat edilen hastalar çalışmaya dahil edildi.

Bulgular: Dört hasta erkek, yedi hasta kadındı. Yaş ortalaması 54,18 idi. Tümör 4 olguda rektumda, 3 olguda anorektal bölgede ve 4 olguda anal kanalda idi. Üç olguya geniş lokal eksizyon, 8 olguya APR uygulandı. Olguların dördü evre I, 6'sı evre II ve 1'i evre III idi. Ortalama tümör boyutu 4,73 cm ve ortalama tümör derinliği 13,6 mm idi. Ortalama metastatik lenf nodu sayısı 10,37 idi. Ortanca sağ kalım 12 aydı.

Sonuç: Anorektal malign melanom, spesifik bulguların olmaması nedeniyle geç ve ileri evrelerde teşhis edilen bir kanser türüdür. ARMM nadir olmasına rağmen, rektal kanama, ağrı, hemoroid ve barsak alışkanlıklarındaki değişiklikler gözlendiğinde ARMM akılda tutulmalıdır.

Anahtar Kelimeler: Anorektal malign melanom, abdominoperineal rezeksiyon, geniş lokal eksizyon, prognoz

Doi: $10.47717 /$ turkjsurg. 2021.4810 